\title{
Response of Eight Market Classes of Dry Bean (Phaseolus vulgaris L.) to Pendimethalin
}

\author{
Nader Soltani $^{{ }^{*}}$, Robert E. Nurse ${ }^{2}$, Christy Shropshire ${ }^{1}$, Peter H. Sikkema ${ }^{1}$ \\ ${ }^{1}$ University of Guelph Ridgetown Campus, Ridgetown, Canada; ${ }^{2}$ Agriculture and Agri-Food Canada, Harrow, Canada. \\ Email: "nsoltani@ridgetownc.uoguelph.ca
}

Received October $5^{\text {th }}$, 2010; revised November $8^{\text {th }}$, 2011; accepted November 20 2011.

\begin{abstract}
There is little information on the tolerance of dry bean to pendimethalin. Field studies were conducted in 2007 to 2009 at Exeter, Ontario and in 2008 and 2009 at Ridgetown, Ontario to evaluate tolerance of black, cranberry, kidney, otebo, pink, pinto, Small Red Mexican (SRM) and white bean to pendimethalin applied preplant incorporated (PPI) at 1080 and $2160 \mathrm{~g} \cdot a . i \cdot h a^{-1}$. Pendimethalin PPI caused minimal injury in most market classes of dry bean at 1 and 2 weeks after emergence (WAE). There was no injury in various market classes of dry bean with the low dose at 1 and 2 WAE. However, at the high dose there was 0 to 4\% injury at 1 WAE and 0 to 7\% injury at 2 WAE in black, cranberry, kidney, otebo, pink, pinto, SRM and white bean. Pendimethalin PPI was more injurious in white bean than in black, cranberry, kidney, otebo, pink, pinto and SRM bean. Pink and SRM bean exhibited the most tolerance to pendimethalin applied PPI at $1080 \mathrm{~g} \cdot a \mathrm{i} \cdot h \mathrm{~h}^{-1}$ or $2160 \mathrm{~g} \cdot \mathrm{ai} \cdot \mathrm{ha}^{-1}$. Pendimethalin caused no adverse effect on plant height, shoot dry weight, seed moisture content and seed yield of black, cranberry, kidney, otebo, pink, pinto, SRM and white bean. Based on these results, there is an adequate margin of crop safety for pendimethalin applied PPI at the proposed dose of $1080 \mathrm{~g} \cdot a \mathrm{i} \cdot \mathrm{ha}^{-1}$ in black, cranberry, kidney, otebo, pink, pinto, SRM and white bean in Ontario.
\end{abstract}

Keywords: Black Bean, Cranberry Bean, Kidney Bean, Otebo Bean, Pendimethalin, Pink Bean, Small Red Mexican Bean, Phaseolus vulgaris L., White Bean

\section{Introduction}

Dry bean (Phaseolus vulgaris L.) is an important crop grown in southern Ontario since the 1940's [1]. The Ontario white bean and Ontario coloured bean industry include about 1000 growers that plant approximately 95,000 ha and produce approximately 77,000 MT of dry bean with annual farm-gate value of about $\$ 70,000,000$ [2]. Dry bean is an alternative high-value crop that producers can grow in rotation with wheat (Triticum aestivum L.), field corn (Zea mays L.) and soybean [Glycine max (L.) Merr.] in southwestern Ontario. Major market classes (same geographic origin, gene pool, seed size and seed color) of dry bean grown in Ontario include black, cranberry, kidney and white (navy) bean. In recent years other speciality market classes of dry beans such as otebo, pink, pinto and Small Red Mexican (SRM) bean are also produced as farmers diversify their production and pursue new global markets, especially those in Asia. Weed control is one of the most critical problems facing growers as dry bean is a poor competitor with weeds. Weeds compete with dry bean for moisture, nutrients and light and can cause significant seed yield and seed quality losses if not adequately controlled [3-7]. Ontario dry bean producers have a limited number of herbicide options available to them for grass and broadleaf weed control. More research is needed to identify herbicides that provide consistent annual grass and broadleaf weed control and are safe to use on dry bean.

Pendimethalin is a dinitroaniline selective herbicide used to control most annual grasses and certain broadleaf weeds in field corn, soybean, rice, potatoes, lettuce, stone fruit, cotton, peanuts, sunflowers and berry fruits including strawberry [8]. Pendimethalin is primarily absorbed by root. It inhibits cell division and cell elongation. Susceptible plants die shortly after germination or following emergence from the soil [8]. Pendimethalin can be used preplant incorporated (PPI), preemergence (PRE), and early postemergence (EPOST) [8,9]. Pendimethalin controls annual grasses such as barnyardgrass (Echinochloa crusgalli (L.) Beauv.), smooth crabgrass (Digitaria ischaemum (Schreb) Muhl.), large crabgrass (Digitaria sanguinalis (L.) Scop), fall panicum (Panicum dichotomiflorum Michx.), giant foxtail (Setaria faberii 
Herrm.), green foxtail (Setaria viridis (L.) Beauv.), yellow foxtail (Setaria glauca (L.) Beauv.), and certain annual broadleaf weed such as common lambsquarters (Chenopodium album L.), common redroot pigweed (Amaranthus retroflexus L.), common chickweed (Stellaria media (L.) Cyrillo) and nightshades (Solanum spp.) [8,9].

Sensitivity of dry bean to herbicides has been attributed to application dose, application timing, market class, cultivar and environmental conditions [6,10-13]. There is little published information on the response of various market classes of dry bean to pendimethalin. If tolerance is adequate, the registration of pendimethalin would provide Ontario dry bean producers with a new herbicide for the control of annual grasses and small seeded broadleaved weeds in dry bean.

The objective of this research was to determine the tolerance of eight cultivars of dry bean representing eight market classes of dry bean to penthimethalin PPI at the dose of 1080 and $2160 \mathrm{~g} \cdot \mathrm{ai} \cdot \mathrm{ha}^{-1}$, representing $1 \times$ and $2 \times$ the manufacturer's recommended dose.

\section{Materials and Methods}

Field studies were conducted in 2007 to 2009 at the Huron Research Station, Exeter, Ontario and in 2008 and 2009 at the University of Guelph Ridgetown Campus, Ridgetown, Ontario. The soil at Exeter was a Brookston loam/clay loam (Orthic Humic Gleysol, mixed, mesic, and poorly drained) with $32 \%$ sand, $41 \%$ silt, $27 \%$ clay, $4.6 \%$ organic matter and $\mathrm{pH}$ of 7.9 in $2007,33 \%$ sand, $35 \%$ silt, $32 \%$ clay, $3.4 \%$ organic matter and $\mathrm{pH}$ of 7.9 in 2008 , and $38 \%$ sand, $41 \%$ silt, $21 \%$ clay, $3.7 \%$ organic matter and $\mathrm{pH}$ of 7.8 in 2009. The soil at Ridgetown was a Wattford (Grey-Brown Brunisolic, mixed, mesic, sandy, and imperfectly drained)-Brady (Gleyed Brunisolic GreyBrown Luvisol, mixed, mesic, sandy, and imperfectly drained) with $56 \%$ sand, $27 \%$ silt, $17 \%$ clay, $5.4 \%$ organic matter and pH of 6.7 in 2008 and 38\% sand, 41\% silt, $21 \%$ clay, $3.7 \%$ organic matter and $\mathrm{pH}$ of 7.8 in 2009. Seedbed preparation at all sites consisted of autumn moldboard plowing followed by two passes with a field cultivator in the spring.

Experiments were arranged in a completely randomized block design in a two way factorial arrangement with four replications. Factor 1 was market class of dry bean and factor 2 was pendimethalin PPI dose (1080 and $\left.2160 \mathrm{~g} \cdot \mathrm{ai} \cdot \mathrm{ha}^{-1}\right)$. A non-treated check was included in each trial representing the zero dose. Plots were $6 \mathrm{~m}$ wide (8 rows spaced $0.75 \mathrm{~m}$ apart) and $10 \mathrm{~m}$ long at Exeter and $6 \mathrm{~m}$ wide and $8 \mathrm{~m}$ long at Ridgetown. Within each plot there was one row of black ("Black Knight"), cranberry (“Etna”), kidney ('Red Hawk'), otebo ("Hime”), pink (“Sedona”), pinto (“GTS 900”), Small Red Mexican
("Merlot”) and white (“OAC Rex") bean. Beans were planted to a depth of $5 \mathrm{~cm}$ in late May to early June of each year at the rate of 200,000 seeds ha ${ }^{-1}$.

The PPI application of pendimethalin was made to the soil surface one day before planting and was immediately incorporated. Herbicide applications were made with a $\mathrm{CO}_{2}$-pressurized backpack sprayer calibrated to deliver $200 \mathrm{~L} \cdot \mathrm{ha}^{-1}$ of spray solution at a pressure of 200 kPa using 8002 flat-fan nozzles (Hypro ULD 120-02 nozzle tips, Spraying Systems Co., P.O. Box 7900. Wheaton, IL 60188). The boom was $2.5 \mathrm{~m}$ wide with six nozzles spaced $0.5 \mathrm{~m}$ apart. Plots were maintained weed free by cultivation and hand hoeing as required to eliminate the confounding effect of weed interference.

Estimates of crop injury were evaluated visually 1, 2 and 4 weeks after emergence (WAE) using a scale of 0 to $100 \%$ where a rating of 0 was defined as no visible plant injury and a rating of 100 was defined as plant death. Ten plants per plot were randomly selected and the height from the soil surface to the highest growing point was measured $4 \mathrm{WAE}$. At $6 \mathrm{WAE}$, a $1 \mathrm{~m}$ section of row for each cultivar was hand harvested at ground level, oven dried at $60^{\circ} \mathrm{C}$ to a constant weight and the dry weight was recorded. Yields were measured at crop maturity by hand-harvesting the remaining $9 \mathrm{~m}$ from each plot at Exeter and $7 \mathrm{~m}$ from each plot at Ridgetown and threshed in a plot combine. Crops were considered physically mature when $90 \%$ of pods in the untreated plots of each cultivar had turned from green to a golden colour. All yields were adjusted to $18 \%$ moisture and seed moisture content was determined.

All data were subjected to analysis of variance (ANOVA) using SAS statistical software (Statistical Analysis Systems, version 9. Box 8000, SAS Institute Inc., Cary, NC 27512). Variance analyses combined over years and locations were performed using the Proc Mixed procedure of SAS. Variances were partitioned into the random effects of locations, years, and years by locations, blocks within years by locations, and their interactions with fixed effects, and into the fixed effects of herbicide treatment, market class and herbicide by market class. Significance of random effects were tested using a Z-test of the variance estimate and fixed effects were tested using F-tests. Error assumptions of the variance analyses (random, homogeneous, normal distribution of error) were confirmed using residual plots and the Shapiro-Wilk normality test. To meet assumptions of the normality, injury at 2 WAE and shoot dry weight data were squareroot transformed and injury at $4 \mathrm{WAE}$ and seed moisture content were log-tranformed. Means were compared using Fisher's protected LSD. The Type I error was set at 0.05 for all statistical comparisons. 


\section{Results and Discussion}

Analysis of variance indicated that location by market class by herbicide treatment interactions were significant for all injury data therefore, Exeter 2008 was analyzed separately (for injury 1 and 2 WAE) and is the only injury data presented because Exeter 2007 \& 2009 and Ridgetown 2008 and 2009 injury were zero and could not be analyzed properly (Table 1). For injury 4 WAE, Exeter 2008 and 2009 were the only non-zero locations and could be combined with each other. Higher in- jury at Exeter compared to Ridgetown could be due to higher rainfall at Exeter after application that moved the pendimethalin into the dry bean root zone. Location by market class by herbicide treatment interactions were not significant for the remaining variables and all three data sets were analyzed together. Seed moisture content was not significant for any interaction, therefore data are not presented. For the main effects, Market class and Rate were significant for injury 1 and 2 WAE (Table 1). Market class was significant for dry weight and yield.

Visual injury symptoms caused by pendimethalin in dry bean included reduced emergence, hypocotyl swelling, stem brittle at the soil line, and growth reduction. Dry bean growers in Ontario generally don't like greater than 5\% injury in their field. Pendimethalin PPI caused minimal injury in most market classes of dry bean at 1 and 2 WAE (Table 1). There was no injury in any market class of dry bean when pendimethalin applied PPI at 1080 g.ai ha ${ }^{-1} 1$ and 2 WAE (Table 2). However, pendimethalin applied PPI at $2160 \mathrm{~g} \cdot \mathrm{ai} \cdot \mathrm{ha}^{-1}$ caused 0 to $4 \%$ injury at $1 \mathrm{WAE}$ and 0 to $7 \%$ injury at $2 \mathrm{WAE}$ in black, cranberry, kidney, otebo, pink, pinto, SRM and white bean. Other studies have shown little or no visible injury in adzuki, kidney, pinto, otebo-, and white bean with other dinitroanalide herbicides such as trifluralin [14-18]. Pendimethalin PPI was more injurious in white bean than in black, cranberry, kidney, otebo, pink, pinto and SRM bean. Pink and SRM bean exhibited the greastest tolerance to pendimethalin. This is similar to other studies that have shown differential sensitivity of dry bean $[4,6]$. We have also found significantly higher sensitivity in black and white bean market classes compared to cranberry and kidney bean market classes in response to soil applied herbicides such as $S$-metolachlor, imazethapyr, flumioxazin and pyroxasulfone [19-23]. Market classes of dry bean vary in their gene pool as they originate from different geographic regions which can affect their tolerance to herbicides [24-26].

Table 1. Significance of main effects and interactions for percent visual injury, height, shoot dry weight, and yield of dry bean. Means followed by the same letter within a column are not significantly different according to Fisher's Protected LSD at $P<$ 0.05. Means for a main effect were separated only if there was no significant interaction involving that main effect ${ }^{\text {a }}$.

\begin{tabular}{|c|c|c|c|c|c|c|}
\hline \multirow[b]{2}{*}{ Main effects } & \multicolumn{3}{|c|}{ Dry bean injury } & \multirow[b]{2}{*}{$\begin{array}{c}\text { Height }^{\mathrm{e}} \\
\mathrm{cm}\end{array}$} & \multirow[b]{2}{*}{$\begin{array}{c}\text { Dry weight }{ }^{\mathbf{e}} \\
\mathrm{g} \cdot \mathrm{m} \cdot \mathrm{row}^{-1}\end{array}$} & \multirow[b]{2}{*}{$\begin{array}{l}\text { Yield }^{\mathbf{e}} \\
\mathrm{t} \cdot \mathrm{ha}^{-1}\end{array}$} \\
\hline & $1 \mathrm{WAE}^{\mathrm{bc}}$ & $\begin{array}{c}2 \mathbf{W A E}^{\mathbf{c}} \\
\%\end{array}$ & 4 WAE $^{d}$ & & & \\
\hline Variety of dry bean & $* *$ & * & NS & NS & $* *$ & $* *$ \\
\hline Black & 0.6 & 1.6 & 0.4 & 53 & $54 \mathrm{c}$ & $3.00 \mathrm{a}$ \\
\hline Cranberry & 0 & 0.7 & 0.2 & 51 & $68 \mathrm{ab}$ & $2.33 \mathrm{c}$ \\
\hline Kidney & 0 & 1.3 & 0.3 & 52 & $61 \mathrm{bc}$ & $1.83 \mathrm{~d}$ \\
\hline Otebo & 0.6 & 1.0 & 0.7 & 51 & $67 \mathrm{ab}$ & $2.86 \mathrm{a}$ \\
\hline Pink & 0 & 0 & 0.1 & 58 & $67 \mathrm{ab}$ & $2.38 \mathrm{bc}$ \\
\hline Pinto & 0 & 0.7 & 0.3 & 54 & $70 \mathrm{a}$ & $2.67 \mathrm{abc}$ \\
\hline Small Red Mexican & 0 & 0 & 0.6 & 56 & $54 \mathrm{c}$ & $2.42 \mathrm{bc}$ \\
\hline White & 1.9 & 2.6 & 0.6 & 52 & $56 \mathrm{c}$ & $2.74 \mathrm{ab}$ \\
\hline Pendimethalin rate $\left(\mathrm{g} \cdot a i \cdot h a^{-1}\right)$ & $* *$ & $* *$ & $* *$ & NS & NS & NS \\
\hline 0 & 0 & 0 & $0 \mathrm{a}$ & 54 & 65 & 2.58 \\
\hline 1080 & 0 & 0 & $0 \mathrm{a}$ & 54 & 60 & 2.51 \\
\hline 2160 & 0.8 & 2.2 & $0.9 \mathrm{~b}$ & 53 & 61 & 2.49 \\
\hline \multicolumn{7}{|l|}{ Interaction } \\
\hline $\mathrm{V} \times \mathrm{R}$ & $* *$ & $*$ & NS & NS & NS & NS \\
\hline
\end{tabular}

${ }^{\mathrm{a}}$ Abbreviations: WAE, Week after emergence; $\mathrm{V}$, variety of dry bean; R, pendimethalin rate; NS, not significant at $P=0.05$ level; ${ }^{\mathrm{b}}$ Significance at $P<0.05$ and $P<0.01$ levels denoted by * and ${ }^{* *}$, respectively; ${ }^{\mathrm{C}}$ Exeter 2008 data only; ${ }^{\mathrm{d}}$ Exeter 2008 and 2009 data only; ${ }^{\mathrm{e}}$ Data are averaged for locations and years. 
Table 2. Percent visual injury 1 and 2 weeks after emergence (WAE) at Exeter (2008), Ontario, Canada for eight dry bean varieties at two doses of pendimethalin. Means followed by the same letter within a column (a - c) or row (Y - Z) in each section are not significantly different according to Fisher's Protected LSD at $P<0.05$.

\begin{tabular}{|c|c|c|c|c|}
\hline \multirow[b]{2}{*}{ Dry bean variety by variable } & \multicolumn{3}{|c|}{ Pendimethalin dose $\left(\mathrm{g} \cdot \mathrm{ai} \cdot \mathrm{ha}^{-1}\right.$ ) } & \multirow[b]{2}{*}{ SE } \\
\hline & $\mathbf{0}$ & 1080 & 2160 & \\
\hline & \multicolumn{3}{|c|}{$\%$} & \\
\hline \multicolumn{5}{|l|}{ Injury 1 WAE } \\
\hline Black & 0 a Z & 0 a Z & 1.2 a Z & 0.6 \\
\hline Cranberry & 0 a Z & $0 \mathrm{a} \mathrm{Z}$ & 0 a Z & 0 \\
\hline Kidney & 0 a Z & 0 a Z & 0 a Z & 0 \\
\hline Otebo & 0 a Z & $0 \mathrm{a} \mathrm{Z}$ & 1.2 a Z & 0.6 \\
\hline Pink & 0 a Z & $0 \mathrm{a} \mathrm{Z}$ & 0 a Z & 0 \\
\hline Pinto & 0 a Z & $0 \mathrm{a} \mathrm{Z}$ & 0 a Z & 0 \\
\hline Small Red Mexican & 0 a Z & 0 a Z & 0 a Z & 0 \\
\hline White & 0 a Z & $0 \mathrm{a} \mathrm{Z}$ & $3.8 \mathrm{~b} \mathrm{Y}$ & 0.9 \\
\hline \multicolumn{5}{|l|}{ Injury 2 WAE } \\
\hline Black & 0 a Z & 0 a Z & 4.2 bc $\mathrm{Y}$ & 1.3 \\
\hline Cranberry & $0 \mathrm{aZ}$ & 0 a Z & $1.8 \mathrm{ab} \mathrm{Z}$ & 0.8 \\
\hline Kidney & 0 a Z & 0 a Z & 3.4 bc Y & 1.6 \\
\hline Otebo & 0 a Z & 0 a Z & $2.6 \mathrm{~b} \mathrm{Y}$ & 1.3 \\
\hline Pink & $0 \mathrm{a} Z$ & 0 a Z & 0 a Z & 0 \\
\hline Pinto & 0 a Z & 0 a Z & $1.8 \mathrm{ab} \mathrm{Z}$ & 0.8 \\
\hline Small Red Mexican & 0 a Z & 0 a Z & 0 a Z & 0 \\
\hline White & $0 \mathrm{a} \mathrm{Z}$ & $0 \mathrm{a} \mathrm{Z}$ & 7.3 с Y & 1.6 \\
\hline
\end{tabular}

Plant height is important in dry bean production as shorter plants can have greater shatter loss at the cutter bar of the combine during harvesting and therefore reduce harvested yield. Pendimethalin applied PPI at $1080 \mathrm{~g} \cdot \mathrm{ai} \cdot \mathrm{ha}^{-1}$ or 2160 g.ai:ha ${ }^{-1}$ had no effect on plant height in black, cranberry, kidney, otebo, pink, pinto, SRM and white bean (Table 1). In other studies, there was differential height reduction among market classes of dry bean in response to soil applied herbicides such as $S$-metolachlor, imazethapyr, flumioxazin and pyroxasulfone [18-22]. However, other studies have shown no significant height reduction in dry bean with other dinitroanaline herbicides such as trifluralin in adzuki and otebo bean [15,18,21].

Shoot dry weight for each market class was not affected with pendimethalin applied PPI at $1080 \mathrm{~g} \cdot \mathrm{ai} \cdot \mathrm{ha}^{-1}$ or $2160 \mathrm{~g} \cdot \mathrm{ai} \cdot \mathrm{ha}^{-1}$ but there were differences among shoot dry weights of various market classes of dry bean (Table 1). White, SRM and black bean had lower shoot dry weights than cranberry, kidney, otebo and pink bean which had lower dry weight than pinto bean although results were not always statistically significant. In other studies root and shoot dry weight was not adversely affected with other dinitroanaline herbicides such as trifluralin in adzuki and otebo bean [15,18,21].

Seed moisture content at harvest is important in dry bean production. Dry bean should have a seed moisture content of about $18 \%$ at harvest. Low seed moi- sture can result in mechanical injury (split seed coats) while high seed moisture content can increase respiration and promote growth of seed embryos, insects and fungi. Pedimethalin applied PPI at $1080 \mathrm{~g} \cdot \mathrm{ai} \cdot \mathrm{ha} \mathrm{a}^{-1}$ or $2160 \mathrm{~g} \cdot \mathrm{ai}^{\mathrm{h}} \mathrm{ha}^{-1}$ had no effect on seed moisture content in black, cranberry, kidney, otebo, pink, pinto, SRM and white bean (Data not shown).

There were differences in seed yield among the various market classes of dry bean but seed yield for each market class was not affected by pendimethalin applied PPI at $1080 \mathrm{~g} \cdot a i \cdot \mathrm{ha}^{-1}$ or $2160 \mathrm{~g} \cdot \mathrm{ai} \cdot \mathrm{ha}^{-1}$ (Table 1). Black, otebo, pinto and white bean had the highest seed yield while cranberry and kidney bean had the lowest yield among various market classes of dry bean evaluated. In other studies Arnold et al. (1993) [14] and Powell et al. (2004) [27] found no seed yield reduction with dinitroanalide herbicides such as trifluralin in pinto and adzuki bean. In other research, we have also seen no adverse effects on seed yield with trifluralin in adzuki, kidney, 
otebo, and white bean [16-18].

\section{Conclusions}

Based on this study pendimethalin applied PPI at the proposed dose of $1080 \mathrm{~g} \cdot \mathrm{ai} \cdot \mathrm{ha}^{-1}$ has an adequate margin of crop safety for used in black, cranberry, kidney, otebo, pink, pinto, SRM and white bean under Ontario environmental conditions. Availability of pendimethalin would provide Ontario dry bean producers with a new herbicide for the control of annual grasses and small seeded broadleaved weeds. Using pendimethalin in a diversified, integrated weed management program could also help reduce the selection intensity for herbicide resistant weeds.

\section{REFERENCES}

[1] Agriculture and Agri-Food Canada, "Crop Profile for Dry Bean in Canada,” Pest Management Centre Pesticide Risk Reduction Program, Agriculture and Agri-Food Canada, Ottawa, 2005, pp. 1-31.

[2] B. McGee, "Field Crop Statistics," Ontario Ministry of Agriculture and Food and Rural Affairs, Toronto, 2010. http://www.omafra.gov.on.ca/english/stats/crops/index.html

[3] R. E. Blackshaw, "Hairy Nightshade (Solanum sarrachoides) Interference in Dry Beans (Phaseolus vulgaris)," Weed Science, Vol. 39, No. 1, 1991, pp. 48-53.

[4] R. G. Wilson and S. D. Miller, "Dry Edible Bean (Phaseolus vulgaris) Responses to Imazethapyr," Weed Technology, Vol. 5, No. 1, 1991, pp. 22-26.

[5] R. G. Wilson, "Wild Proso Millet (Panicum miliaceum) Interference in Dry Bean (Phaseolus vulgaris)," Weed Science, Vol. 41, No. 4, 1993, pp. 607-610.

[6] T. A. Bauer, K. A. Renner, D. Penner and J. D. Kelly, "Pinto Bean (Phaseolus vulgaris) Varietal Tolerance to Imazethapyr," Weed Science, Vol. 43, No. 3, 1995, pp. 417-424.

[7] C. P. Urwin, R. G. Wilson and D. A. Mortensen, "Responses of Dry Edible Bean (Phaseolus vulgaris) Cultivars to Four Herbicides,” Weed Technology, Vol. 10, No. 3, 1996, pp. 512-518.

[8] S. A. Senseman, "Herbicide Handbook," 9th Edition, Weed Science Society of America, Lawrence, 2007, pp. 1-493.

[9] Ontario Ministry of Agriculture and Food and Rural Affairs (OMAFRA), “Guide to Weed Control,” Publication 75, Toronto, 2009, pp. 1-396.

[10] K. A. Renner and G. E. Powell, "Responses of Navy Bean (Phaseolus vulgaris) and Wheat (Triticum aestivum) Grown in Rotation to Clomazone, Imazethapyr, Bentazon, and Acifluorfen," Weed Science, Vol. 40, No. 1, 1992, pp. 127-133.

[11] R. E. Blackshaw and G. Saindon, "Dry Bean (Phaseolus vulgaris) Tolerance to Imazethapyr," Canadian Journal of Plant Science, Vol. 76, No. 4, 1996, pp. 915-919. doi:10.4141/cjps96-153
[12] J. M Van Gessel, W. D. Monks and R. J. Quintin, "Herbicides for Potential Use in Lima Bean (Phaseolus lunatus) Production,” Weed Technology, Vol. 14, No. 2, 2000, pp. 279-286.

doi:10.1614/0890-037X(2000)014[0279:HFPUIL]2.0.CO ;2

[13] I. K. Ward and E. S. Weaver, "Responses of Eastern Black Nightshade (Solanum ptycanthum) to Low Rates of Imazethapyr and Metolachlor," Weed Science, Vol. 44, No. 4, 1996, pp. 897-902.

[14] N. R. Arnold, W. M. Murray, J. E. Gregory and D. Smeal, "Weed Control in Pinto Beans (Phaseolus vulgaris) with Imazethapyr Combinations," Weed Technology, Vol. 7, No. 2, 1993, pp. 361-364.

[15] D. C. McClary, T. L. Raney and T. A. Lumpkin, “Japanese Food Marketing Channels: A Case Study of Azuki Beans and Azuki Products," Washington State University IMPACT Center Rpt., Pullman, 1989, p. 29.

[16] N. Soltani, C. Shropshire, D. E. Robinson and P. H. Sikkema, "Sensitivity of Adzuki Bean (Vigna angularis) to Preplant-Incorporated Herbicides," Weed Technology, Vol. 19, No. 4, 2005, pp. 897-901. doi:10.1614/WT-05-005R1.1

[17] N. Soltani, R. E. Nurse, L. L. Van Eerd, R. J. Vyn, C. Shropshire and P. H. Sikkema, "Weed Control, Environmental Impact and Profitability with Trifluralin Plus Reduced Doses of Imazethapyr in Dry Bean,” Crop Protection, Vol. 29, No. 4, 2010, pp. 364-368.

[18] P. H. Sikkema, D. E. Robinson, C. Shropshire and N. Soltani, "Tolerance of Otebo Bean (Phaseolus vulgaris) to New Herbicides in Ontario,” Weed Technology, Vol. 20, No. 4, 2006, pp. 862-866. doi:10.1614/WT-05-144.1

[19] N. Soltani, C. Shropshire, T. Cowan and P. Sikkema, "Tolerance of Cranberry Beans (Phaseolus vulgaris) to Soil Applications of S-Metolachlor and Imazethapyr," Canadian Journal of Plant Science, Vol. 83, 2003 pp. 645-648. doi:10.4141/P03-006

[20] N. Soltani, C. Shropshire, T. Cowan and P. Sikkema, "Tolerance of Black Beans (Phaseolus vulgaris) to Soil Applications of S-Metolachlor and Imazethapyr," Weed Technology, Vol. 18, No. 1, 2004, pp. 166-173. doi:10.1614/WT-03-044R

[21] N. Soltani, S. Bowley and P. H. Sikkema, "Responses of Dry Beans (Phaseolus vulgaris) to Flumioxazin,” Weed Technology, Vol. 19, No. 2, 2005, pp. 351-358. doi:10.1614/WT-04-146R1

[22] P. Sikkema, N. Soltani, C. Shropshire and T. Cowan, "Sensitivity of Kidney Beans (Phaseolus vulgaris) to Soil Applications of S-Metolachlor and Imazethapyr," Canadian Journal of Plant Science, Vol. 84, No. 1, 2004, pp. 405-407. doi:10.4141/P03-069

[23] P. Sikkema, C. Shropshire and N. Soltani, "Dry Bean Response to Preemergence-Applied KIH-485," Weed Technology, Vol. 21, No. 1, 2007, pp. 230-234. doi:10.4141/P03-069

[24] S. P. Singh, P. Gepts and D. G. Debouck, "Races of Common Bean (Phaseolus vulgaris, Fabaceae,” Econo- 
mic Botany, Vol. 45, No. 3, 1991, pp. 379-396. doi:10.1007/BF02887079

[25] S. P. Singh, J. A. Gutierrez, A. Molina, C. Urrea and P. Gepts, "Genetic Diversity in Cultivated Common Bean: II. Marker-Based Analysis of Morphological and Agronomic Traits," Crop Science, Vol. 31, 1991, pp. 23-29. doi:10.2135/cropsci1991.0011183X003100010005x
[26] S. P. Singh, R. Nodari and P. Gepts, "Genetic Diversity in Cultivated Common Bean: I. Allozymes,” Crop Science, Vol. 31, 1991, pp. 19-23. doi:10.2135/cropsci1991.0011183X003100010004X

[27] G. E. Powell, C. L. Sprague and K. A. Renner, "Adzuki Bean: Weed Control and Production Issues,” 59th North Central Weed Science Proceedings, Vol. 59, 2004, p. 32. 